\title{
Essay
}

\section{Aquaculture Development and Education in Nepal: Potential and Challenges}

\author{
Abhimanyu Shrestha (Corresponding author) \\ Department of Fisheries and Aquaculture \\ Agriculture and Forestry University, Rampur, Nepal \\ E-mail: fisheriesavi@gmail.com
}

\section{Sujita Balami}

Department of Fisheries and Aquaculture

Agriculture and Forestry University, Rampur, Nepal

Puja Banmali

Department of Fisheries and Aquaculture

Agriculture and Forestry University, Rampur, Nepal

\author{
Nisha Shrestha \\ Department of Fisheries and Aquaculture \\ Agriculture and Forestry University, Rampur, Nepal
}

Samantha Farquhar

School of Marine and Environmental Affairs

University of Washington, Seattle, USA

Received: October 21, 2018 Accepted: December 5, 2018

Published: December 12, 2018

doi:10.5296/jei.v4i2.13809 URL: https://doi.org/10.5296/jei.v4i2.13809 


\section{Abstract}

In Nepal, the government has increased the support of fisheries and aquaculture activities to help increase economic productivity and well-being. However, while the potential for such activities are great, workforce is lacking due to education capacity. This essay voices the issues and frustrations of students who aspire to aid in the development of the fisheries and aquaculture sector of Nepal but face obstacles such as political instability, brain drain, and employment.

Keywords: Aquaculture, Development, Brain drain, Political instability, Strikes

\section{Introduction}

The government of Nepal has recently increased their promotion of fisheries and aquaculture activities (Shrestha \& Pant, 2012). The practice of aquaculture especially shows great potential in Nepal. In fact, the Census of Agriculture reports that aquaculture is growing at $8.4 \%$ annually, producing about 50,000 tons. Aquaculture is a relatively new practice that originally started in the 1950s with carp cultivation in the flat Terai Plain region. It has since expanded to higher altitude areas such as the mid-hills with cold-water species (Rai et al., 2005).

Low economic productivity and food security are common problems in Nepal. The annual per capita income (USD \$732) is one of the lowest in the world. Additionally, malnutrition is common. Nearly $41 \%$ of Nepali children under 5 are stunted, while $29 \%$ are underweight and $48 \%$ of pregnant women are anemic (WFP, 2018). However, increasing fisheries production in Nepal can increase food and economic security. For example, Farquhar et al. (2018) showed that a single fish farm in Nepal not only provided, on average, USD $\$ 300(40 \%$ of the per capita GDP) in supplemental income, but also significantly more consumption of fish (which are known to have high protein and essential micronutrients) for a household.

\section{The Problem}

The main governmental body for fisheries in Nepal is the Directorate of Fisheries Development (DoFD) under the Department of Agriculture. Nepal is comprised of 75 districts. Each district has its own District Agriculture Office (DAO) or Governmental Research Station (GRS) where Nepali citizens can visit and receive trainings and extension services from Subject Matter Specialists or Junior Tech Assistants. Overall, the Department of Agriculture has 378 extension offices nationwide. Every agriculture outreach station serves more than 11,000 farmers. One average, one technician is responsible for an average 1,500 farmers (IRIN News, 2013). It is at these DAOs and GRSs where the process of fisheries development should begin. However, many of the DAOs and GRSs do not have specialists in fisheries or aquaculture as it is still emerging in Nepal. Thus, they are not able to properly advise families seeking assistance on starting an aquaculture farm or fisheries management. By consequence, fisheries and aquaculture development is not progressing as it should. This lack of workforce is thought to be fulfilled by recent, eager graduates, but that is not the case in reality. 
Currently there is only one university in Nepal that trains students in Fisheries and Aquaculture - the Agriculture and Forestry University of Nepal (AFU). The university began offering a Bachelor's of Science in Fisheries and Aquaculture in 2010. However, the program is only able to take on 16 students every year making the program incredibly competitive and largely inaccessible. While the professors and instructors of the Department of Fisheries and Aquaculture have been described as excellent by the students - often using their own money to set-up field excursions and research activities - existing issues in the higher administration of the university constantly affect students' ability to learn. Strikes and protests render the university closed for weeks at a time. Strikes are usually due to fights between the students of different political parties in regards to preferential treatment. In the past, students have protested teachers being hired based on their political affiliation rather than their merit, exams being scheduled unfairly, hostel accommodation, among others. While protesting is essential for democracy, many protests at the university have turned violent resulting in physical damage to the university (i.e. rocks thrown through windows), and more seriously, these non-peaceful protests have caused harm to students' health and safety. Last year, two students were hospitalized at the local Chitwan Medical College for severe head and leg injuries from fights incurred during student political protests. Student political leaders that have physically damaged the university or attacked other students have not faced any expulsion from the university.

Most recently, peaceful protests by both students and teachers occurred for nearly 2 months over the university administration giving affiliation to 8 private colleges (The Himalayan Times, 2018). Eventually, the demands of the students and teachers were met, but again students' curriculums were severely affected and delayed. After the university was reopened, some students who were still disgruntled vandalized and set fire to the administrative building of the university (The Himalayan Times, 2018). It is because of instances like this that students of the 4 year Bachelors of Science Fisheries and Aquaculture program are delayed up to year and a half in earning their degree.

\section{The Future}

Once students do graduate, they usually pursue work in government, with NGOs, or go abroad for studies with the last being the most ideal option. To work for the government, recent graduates must pass an exam that is notorious for being difficult. This exam often intimidates students and deters them from trying. In a recent survey of students from AFU, nearly $52 \%$ intended to go abroad for work or further studies. In this same study, it was identified that poor higher education in Nepal was the leading push factor (Kattel \& Sapkota, 2018). While students cannot be blamed for wanting to leave and make better lives for themselves, this brain drain is stagnating the growth and development of Nepal.

Students are eager. We want to learn. We want to apply our knowledge to help our country. We only need the opportunity. Fisheries and aquaculture development in Nepal cannot be expected to increase with only 16 students are graduating trained in the field every year. Nepal needs to increase its capacity for education. This cannot be done without stable governance and support. Professors should be given more resources to help students and have 
more power to negotiate with higher administration. More universities should include fisheries programs in their course offerings.

Presently, the university system in Nepal is mirroring the national political instability. In the last decade, there have been 10 Prime Ministers. If we want the nation of Nepal to progress and grow - both in fisheries and other sectors - politics must not come between students and education.

\section{References}

Central Bureau of Statistics. (2013). National Census of Agriculture Nepal 2011/12. Retrieved from http://cbs.gov.np/image/data/Agriculture/NationalLevel/NATIONALREPOR T2011_12.pdf

Farquhar, S. D., Khanal, N., Shrestha, M., Farthing, M., \& Bhujel, R. C. (January 17, 2018). Socio-economic impacts of the Women in Aquaculture (WiA) project in Nepal. Kasetsart Journal of Social Sciences. https://doi.org/10.1016/j.kjss.2017.12.014

IRIN News. (2013). The trouble with Nepal's agriculture. Retrieved from http://www. irinnews.org/report/97321/analysis-trouble-nepal's-agriculture

Kattel, R. R., \& Sapkota, M. (2018). Brain drain of agriculture and veterinary graduates to abroad: Evidence from Nepal. Agriculture \& Food Security, 7(1), 61. https://doi.org/10.1186/ s40066-018-0213-1

Rai, A., Bhujel, R., Basnet, S., \&Lamsal, G. (2005). Rainbow Trout (Onchorhynchus mykiss) Culture in the Himalayan Kingdom of Nepal (pp. 1-31). APAARI, FAO Regional Office for Asia and the Pacific, Bangkok, Thailand. Retrieved from http://www.apaari.org/wp-content/ uploads/2009/05/ss_2005_01.pdf

Shrestha, M. K., \& Pant, J. (2012). Small-scale Aquaculture for Rural Livelihoods: Proceedings of the National Symposium on Small-scale Aquaculture for Increasing Resilience of Rural Livelihoods in Nepal (p. 191). Institute of Agriculture and Animal Science, Tribhuvan University, Rampur, Chitwan, Nepal, and The WorldFish Center, Penang, Malaysia. Retrieved from http://pubs.iclarm.net/resource_centre/WF_3347.pdf

The Himalayan Times. (July 30, 2018). Students, teachers protest AFU's decision to provide affiliation to private colleges. Retrieved November 26, 2018, from https://thehimalayan times.com/kathmandu/students-teachers-protest-afus-decision-to-provide-affiliation-to-privat e-colleges

The Himalayan Times. (November 15, 2018). Agriculture and Forestry University in Chitwan vandalised, set ablaze. Retrieved November 26, 2018, from https://thehimalayantimes.com/ nepal/agriculture-and-forestry-university-in-chitwan-vandalised-set-ablaze

WFP (World Food Programme). (2018). Nepal Country Brief (October). Retrieved from http://www.wfp.org/countries/nepal 


\section{Copyright Disclaimer}

Copyright for this article is retained by the author(s), with first publication rights granted to the journal.

This is an open-access article distributed under the terms and conditions of the Creative Commons Attribution license (http://creativecommons.org/licenses/by/3.0/). 